\title{
Nutrient Use Efficiency and Economics of Salad Cucumber Using Drip Fertigation in Naturally Ventilated Polyhouse
}

\author{
A R Jisha Chand \\ Research Scholar, Research \& Development Centre, Bharathiar University, Coimbatore- 641 046, Tamil Nadu, \\ India
}

\begin{abstract}
An experiment was carried out in naturally ventilated polyhouse with four fertigation levels viz., 110 , 100, 90 and 80 per cent recommended dose to determine suitable fertigation dose for salad cucumber under naturally ventilated polyhouse cultivation. Fertigation levels significantly affected $(P<0.05)$ cucumber yield. Plants that received 100 per cent recommended dose of fertigation (175:125:300 $\left.\mathrm{kg} \mathrm{NPK} \mathrm{ha}^{-1}\right)$ showed higher nutrient use efficiency of nitrogen, phosphorous and potassium (508.93, 712.50, $296.88 \mathrm{~kg} \mathrm{ha}^{-1}$ respectively) and recorded significantly higher yield ( $\left.89.06 \mathrm{th} \mathrm{h}^{-1}\right)$ with highest water use efficiency $\left(6167.78 \mathrm{~kg} \mathrm{ha}^{-1} \mathrm{~cm}^{-1}\right)$. The economic analysis of cucumber production revealed that 100 per cent recommended dose of fertigation has resulted into maximum Benefit Cost $(B C)$ ratio of 3.42. Both increased and decreased fertigation levels showed almost equal yield which is significantly less than 100 per cent recommended dose.
\end{abstract}

Keywords: Economics, Fertigation, Naturally ventilated polyhouse, Nutrient use efficiency, Salad cucumber

\section{Introduction}

Vegetable production in Indian Agriculture has wider scope for increasing the income of marginal and small farmers. Vegetables have vast potential in gaining foreign exchange through export. The vegetable growers are looking for new ways to achieve superior quality produce with higher yield. Among the vegetables, salad cucumber is a crop of commercial importance. Protected cultivation of vegetables provides the best way to increase the productivity and quality of vegetables, especially cucurbits. Naturally ventilated polyhouses are highly suitable for year round cultivation of parthenocarpic salad cucumber varieties. The yield potential of vegetables and fruit in a naturally ventilated polyhouse is generally higher than in open field production. As yield potential increases the need for nutrients also increases.

The challenge for agriculture over the coming decades will be to use the plant nutrients in a sustainable way. Sustainability of any system requires optimal utilization of resources such as water, fertilizer and soil. Fertilizer management is the most important agro-technique, which controls development, yield and quality of a crop. Every attempt is therefore necessary, in achieving this objective of higher water and fertilizer use efficiency. Under these circumstances, drip fertigation, which is known to be hi-tech and efficient way of applying fertilizers through irrigation system as a carrier and distributor of crop nutrients, holds bright promise (Magen, 1995). Maximization of crop yield, quality and minimization of leaching loss of nutrients below the rooting zone could be achieved by managing fertilizer concentrations in measured quantities of irrigation water using drip irrigation (Hagin and Lowengart, 1995). When fertilizer is applied through drip irrigation, it was observed that the yield has been increased and about 30 per cent of the fertilizer could be saved (Sivanappan and Ranghaswami, 2005). Fertigation is supplying fertilizers along with irrigation is one of the most effective convenient methods of supplying nutrients of water according to the specific requirements of the crop to maintain optimum soil fertility and to increase the quality of the produce (Shingure et al., 1999). Fertigation is the most efficient method of fertilizer application, as it ensures application of the fertilizers directly to the plant roots (Rajput \& Patel, 2002). Fertigation allows nutrient placement directly into the plant root zone during critical periods of nutrient demand (Mikkelsen, 1989).

The current problem with large scale cultivation of cucumber is that unreasonable water and fertilizer management system (high fertilizer application and inefficient irrigation) not only caused unnecessary waste of water and fertilizer resources, but also led to shallow groundwater nitrate pollution and other environmental problems (Zhang et al., 2010). The present study was conducted to determine nutrient use efficiency and economics of salad cucumber through fertigation in order to find out the most suitable fertigation dose for salad cucumber under naturally ventilated polyhouse cultivation.

\section{Material And Methods}

The experiment was conducted inside the Naturally Ventilated Polyhouse (NVPH) of $292 \mathrm{~m}^{2}$ area located at Precision Farming Development Centre, KCAET, Tavanur, Malappuram District in Kerala during September- December 2013. The soil of the experimental site was well drained laterite soil. The experimental 
setup consisted of screen filter, main, sub mains, laterals, drippers and other accessories required for drip irrigation. A 5 HP submersible pump was used to lift water from the bore well and supply to the drip irrigated plot. The main and sub main pipelines used for drip irrigation were made of PVC pipes of $63 \mathrm{~mm}$ and $50 \mathrm{~mm}$ diameter respectively. Linear Low Density Poly Ethylene (LLDPE) pipes of $12 \mathrm{~mm}$ diameter were used for laterals in the drip irrigation treatments. Drippers of 4 litres per hour (lph) capacity were fitted on the laterals at a spacing of $90 \mathrm{~cm}$. Fertilizer pump is used for fertigation. The application of fertilizer to various treatments was controlled by using control valves provided in the sub main and lateral flow control valves provided at the off take of laterals. The fertilizer sources for supplying $\mathrm{N}$ and $\mathrm{K}$ through drip irrigation were urea and muriate of potash respectively. Phosphorous was applied as top dressing in the form of super phosphate. Fertigation was done once in three days, from planting to the end of the crop.

The experiment was laid out under completely randomized block design with salad cucumber variety Hilton F1 as the test crop. Spacing adopted for single row planting was $90 \mathrm{~cm}$ x $90 \mathrm{~cm}$ on raised beds with a spacing of $50 \mathrm{~cm}$ between beds. The field layout plan for the experimental plots is depicted in Fig. 1. The experiment was carried out in completely randomized block design with four treatments and four replications. The treatment details were T1: 80 per cent recommended dose of NPK; T2: 90 per cent recommended dose of NPK; T3: 100 per cent recommended dose of NPK; T4: 110 per cent recommended dose of NPK.

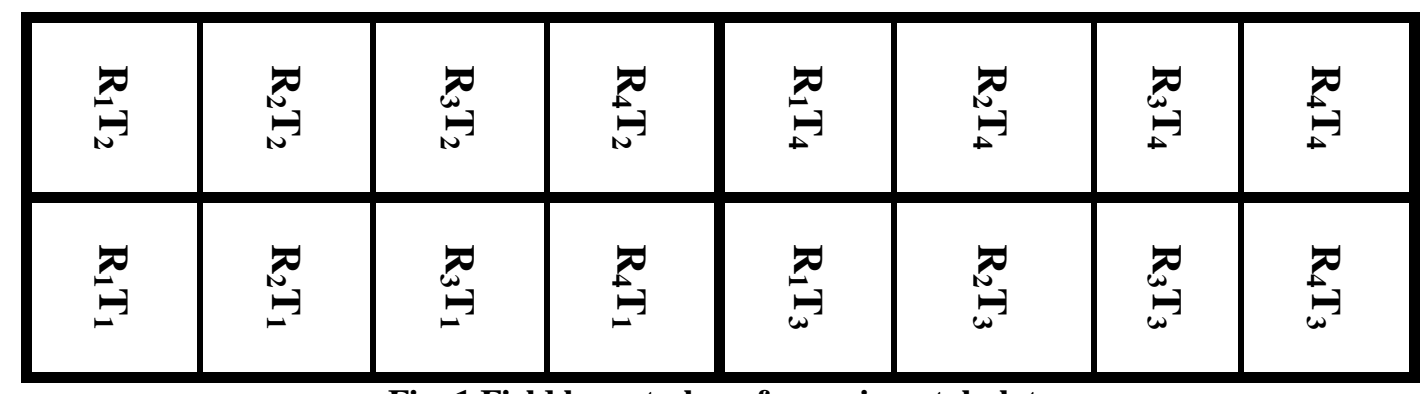

Fig. 1 Field layout plan of experimental plots

Plants were pruned to a single stem by removing lateral shoots. Fruits set on nodes of the main stem and lateral shoot. Harvesting was started 55 days after sowing. As practiced by commercial growers, curved or deformed fruits were removed from the plant during pruning operations and marketable immature fruits were harvested in 2-3 days and then weighed. The number of fruits was also counted.

Statistical analysis of the data was performed using a completely randomized design with four replications. The analysis of variance was also accounted for factors. The level of the significant difference (LSD at $\mathrm{P}<0.05$ ) was used in the ANOVA to test the effect of fertigation treatments on different response variables.

Water use efficiency (WUE) and nutrient use efficiency (NUE) of each treatment was computed using the following equations:

WUE = Weight of marketable produce of the crop $\left(\mathrm{kg} \mathrm{ha}^{-1}\right) /$ Depth of water used $(\mathrm{cm})$

NUE = Yield $\left(\mathrm{kg} \mathrm{ha}^{-1}\right) /$ Total quantity of nutrient applied $\left(\mathrm{kg} \mathrm{ha}^{-1}\right)$

The expenditure incurred from field preparation to harvest was worked out and expressed as Rs. $\mathrm{ha}^{-1}$. The salad cucumber yield was computed per hectare and the total income was worked out based on the prevailed minimum market rate of Rs. 30/- per kg. The net return was calculated by subtracting the cost of cultivation from gross return. The cost of naturally ventilated polyhouse and drip system for one hectare was worked out based on current market rates. The life of the NVPH was assumed to be 10 years and drip system for 6 years. Prevailing market price of NVPH and drip components obtained from a standard firm was used. Interest on capital investment was taken as 8 per cent per annum. The Benefit Cost ratio (BCR) was worked out by using the formula suggested by Palaniappan (1985):

BCR = Gross return $\left(\right.$ Rs. ha $\left.^{-1}\right) /$ Total cost of cultivation $\left(\right.$ Rs. ha $\left.{ }^{-1}\right)$

\section{Results And Discussion}

Crop yield is always an important effective and economic index consideration in the crop development. The number of fruits per plant is an important determinant of yield in salad cucumber. The highest mean fruit weight $\left(7.215 \mathrm{~kg} \mathrm{plant}^{-1}\right)$, fruit number (48), and yield $\left(89.06 \mathrm{t} \mathrm{ha}^{-1}\right)$ were found in T3: 100 percent recommended dose of NPK (175:125:300 kg NPK ha $\left.{ }^{-1}\right)$ and the lowest mean fruit weight (4.405 kg plant $\left.{ }^{-1}\right)$, fruit number (30), and yield $\left(54.38 \mathrm{t} \mathrm{ha}^{-1}\right)$ in the lowest level of fertigation at $80 \%$ (Table 1). Fertigation treatments had significant effects $(\mathrm{P}<0.05)$ on yield. However, interaction within groups was found to be non-significant (Table 2). When a multiple comparison was made using Post Hoc test, yield from $100 \%$ fertigation level, showed significant difference. There was no significant difference among other three treatments. The graph represents the effect of fertigation levels on cucumber yield (Fig. 2). 
Nutrient Use Efficiency and Economics of Salad Cucumber Using Drip Fertigation in Naturally

Table 1. Fruit characteristics of salad cucumber with various fertigation treatments

\begin{tabular}{cccc}
\hline Treatment & Fruit number $\left(\right.$ plant $\left.^{-1}\right)$ & Fruit weight $\left(\mathrm{kg} \mathrm{plant}^{-1}\right)$ & Fruit Yield $\left(\mathrm{t} \mathrm{ha}^{\mathrm{l}}\right)$ \\
\hline T1 & $30^{\mathrm{a}}$ & $4.405^{\mathrm{a}}$ & $54.38^{\mathrm{a}}$ \\
T2 & $33^{\mathrm{a}}$ & $4.938^{\mathrm{a}}$ & $60.96^{\mathrm{a}}$ \\
T3 & $48^{\mathrm{b}}$ & $7.215^{\mathrm{b}}$ & $89.06^{\mathrm{b}}$ \\
T4 & $33^{\mathrm{a}}$ & $4.843^{\mathrm{a}}$ & $59.78^{\mathrm{a}}$ \\
\hline
\end{tabular}

*Mean value of observations from 16 plants in 4 replications.

*Figures given in parenthesis are SE; mean of fruit weight, fruit number and fruit yield in each column with superscripts of same letters do not differ significantly *The mean difference is significant at the 0.05 level.

Table 2. ANOVA of fruit yield of salad cucumber with various fertigation treatments

\begin{tabular}{|c|c|c|c|c|c|c|}
\hline Source & Sum of Squares & df & Mean Square & $\mathrm{F}$ & Sig. & Remarks \\
\hline Block & 228.858 & 3 & 76.286 & 2.460 & 0.129 & NS \\
\hline Treatment & 2924.042 & 3 & 974.681 & 31.427 & 0.000 & $*$ \\
\hline Error & 279.129 & 9 & 31.014 & & & \\
\hline Total & 3432.029 & 15 & & & . & \\
\hline
\end{tabular}

Among the fertigation levels, the highest nitrogen use efficiency $\left(508.93 \mathrm{~kg} \mathrm{ha}^{-1}\right)$, phosphorous use efficiency $\left(712.50 \mathrm{~kg} \mathrm{ha}^{-1}\right)$, potassium use efficiency $\left(296.88 \mathrm{~kg} \mathrm{ha}^{-1}\right)$ indicating comparatively more efficient use of fertilizer and the highest field water use efficiency $\left(6167.78 \mathrm{~kg} \mathrm{ha}^{-1} \mathrm{~cm}^{-1}\right)$ indicating comparatively more efficient use of irrigation water was found at 100\% fertigation level (Table 3) by adopting T3: 100 percent recommended dose of NPK (175:125:300 kg NPK ha $\left.{ }^{-1}\right)$. The graph represents the effect of fertigation levels on nutrient use efficiency (Fig. 3) and water use efficiency of salad cucumber (Fig. 4).

Table 3. Nutrient and water use efficiency of salad cucumber by various fertigation treatments

\begin{tabular}{|c|c|c|c|c|}
\hline Treatment & $\begin{array}{l}\text { Nitrogen use efficiency } \\
\qquad\left(\mathrm{kg} \mathrm{ha}^{-1}\right)\end{array}$ & $\begin{array}{l}\text { Phosphorous use efficiency } \\
\qquad\left(\mathrm{kg} \mathrm{ha}^{-1}\right)\end{array}$ & $\begin{array}{l}\text { Potassium use efficiency } \\
\qquad\left(\mathrm{kg} \mathrm{ha}^{-1}\right)\end{array}$ & $\begin{array}{l}\text { Water use efficiency } \\
\qquad\left(\mathrm{kg} \mathrm{ha}^{-1} \mathrm{~cm}^{-1}\right)\end{array}$ \\
\hline $\mathrm{T} 1$ & $388.43^{b}$ & $543.80^{\mathrm{b}}$ & $226.58^{b}$ & $3765.89^{\mathrm{a}}$ \\
\hline $\mathrm{T} 2$ & $387.01^{\mathrm{b}}$ & $541.81^{\mathrm{b}}$ & $225.75^{\mathrm{b}}$ & $4221.16^{\mathrm{a}}$ \\
\hline $\mathrm{T} 3$ & $508.93^{c}$ & $712.50^{\mathrm{c}}$ & $296.88^{c}$ & $6167.78^{\mathrm{b}}$ \\
\hline $\mathrm{T} 4$ & $310.55^{\mathrm{a}}$ & $434.77^{\mathrm{a}}$ & $181.15^{\mathrm{a}}$ & $4139.94^{\mathrm{a}}$ \\
\hline
\end{tabular}

The maximum net return of Rs. 18,91,007 per ha could be obtained by adopting T3: 100 percent recommended dose of NPK (175:125:300 kg NPK ha ${ }^{-1}$ ) with a Benefit Cost (BC) ratio of 3.42 (Table 4). The pie diagram represents Benefit Cost ratio of salad cucumber with various fertigation treatments (Fig.5).

Table 4. Economics of salad cucumber influenced by fertigation levels

\begin{tabular}{crrrrr}
\hline Treatment & $\begin{array}{r}\text { Crop yield } \\
\left(\mathrm{t} \mathrm{ha}^{-1}\right)\end{array}$ & $\begin{array}{r}\text { Gross Return } \\
\left(\text { Rs. ha }^{-1}\right)\end{array}$ & $\begin{array}{r}\text { Total Cost* } \\
\left(\text { Rs. ha }^{-1}\right)\end{array}$ & $\begin{array}{r}\text { Net Return } \\
\left(\text { Rs. ha }^{-1}\right)\end{array}$ & Benefit Cost ratio \\
\hline T1 & 54.38 & 1631400 & 777743 & 853657 & 2.10 \\
T2 & 60.96 & 1828800 & 779269 & 1049531 & 2.35 \\
T3 & 89.06 & 2671800 & 780793 & 1891007 & 3.42 \\
T4 & 59.78 & 1793400 & 784533 & 1008867 & 2.29 \\
\hline
\end{tabular}

*Includes the costs of drip irrigation system, NVPH construction and cost of cultivation 


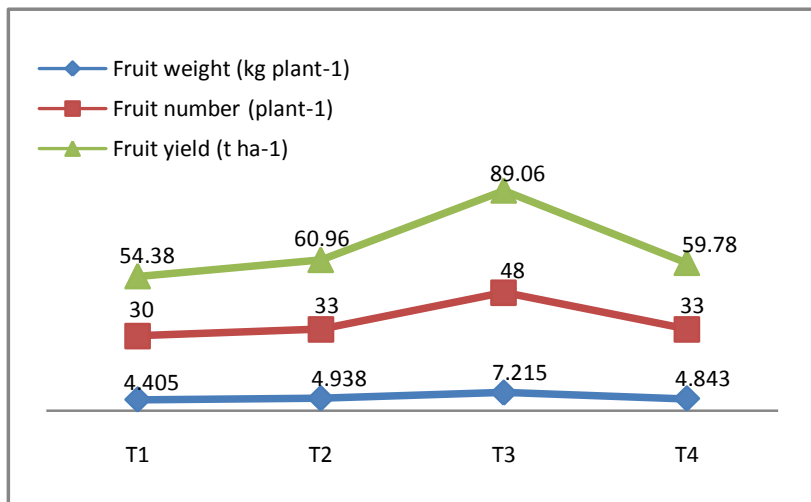

Fig. 2. Effect of fertigation levels on yield

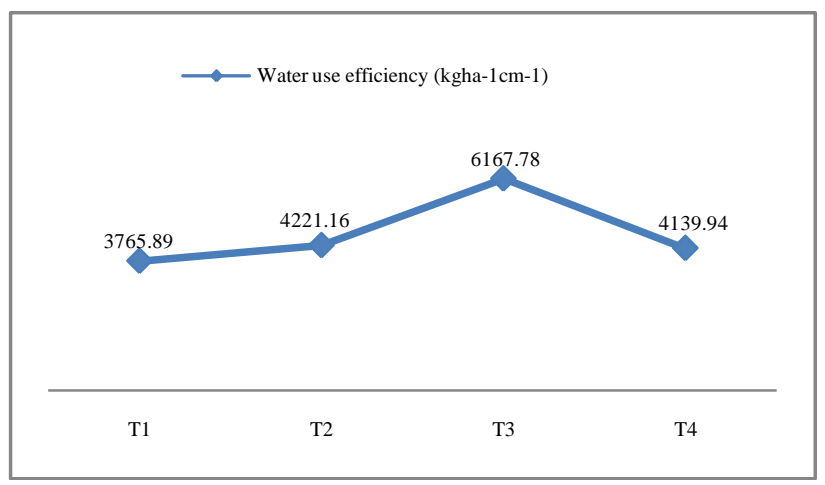

Fig.4. Effect of fertigation levels on WUE

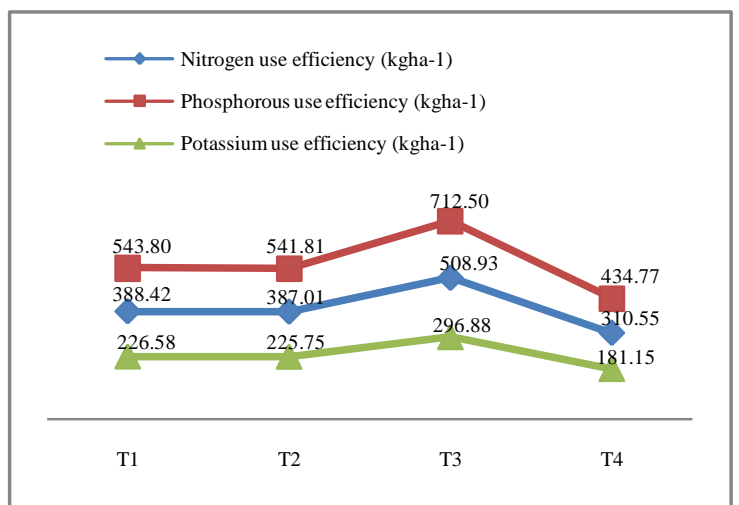

Fig.3. Effect of fertigation levels on NUE

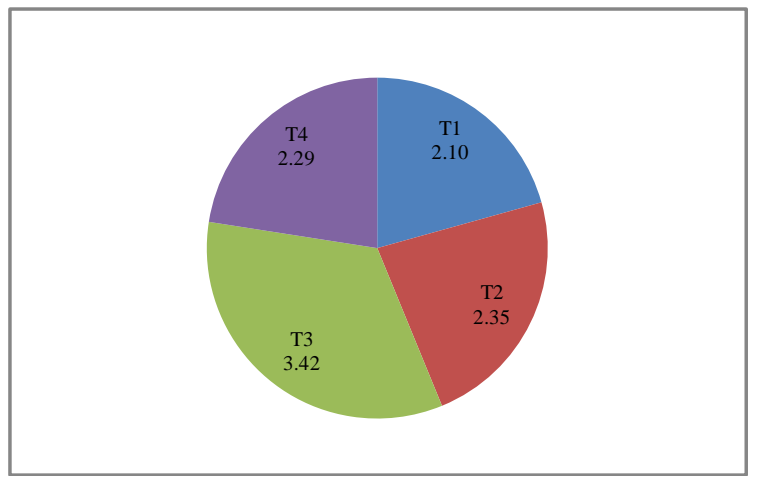

Fig. 5. Effect of fertigation levels on $\mathrm{BC}$ ratio

\section{Conclusion}

Water and fertilizer management is important to cucumber yield. High fertilizer application and inefficient irrigation is the norm in current farming practice, we should take the measure of reducing nutrient application level. We can not only maintain optimal features of cucumber growth and improve water and nutrient use efficiency, but also maintain cucumber yield and improve fruit quality.

The results of the study showed that fertigation levels have significant $(\mathrm{P}<0.05)$ effects on cucumber yield, water and nutrient use efficiency. Higher fruit yield, highest efficiency of water and nutrient use and maximum Benefit Cost ratio can be achieved by T3: 100 per cent recommended dose of NPK (175:125:300 kg NPK $\mathrm{ha}^{-1}$ ), while the other three treatments showed almost uniform yield which is significantly less than 100 percent recommended dose. Thus T3: 100 percent recommended dose of NPK (175:125:300 $\left.\mathrm{kg} \mathrm{NPK} \mathrm{ha}^{-1}\right)$ was the most effective treatment with highest nutrient use efficiency of nitrogen, phosphorous and potassium $\left(508.93,712.50,296.88 \mathrm{~kg} \mathrm{ha}^{-1}\right.$ respectively), higher water use efficiency $\left(6167.78 \mathrm{~kg} \mathrm{ha}^{-1} \mathrm{~cm}^{-1}\right)$, higher yield $\left(89.06 \mathrm{tha}^{-1}\right)$ and maximum Benefit Cost (BC) ratio (3.42).

Based on the result of the present study, it can be concluded that, the application of 100 percent recommended dose of NPK (175:125:300 kg NPK ha $\left.{ }^{-1}\right)$ is the best fertigation dose recommendation for salad cucumber grown under naturally ventilated polyhouse in order to get higher economical cucumber yield.

\section{Acknowledgements}

The author is thankful to Dr. Abdul Hakkim V M, Principal Investigator, Precision Farming Development Centre, Kelappaji College of Agricultural Engineering and Technology, Tavanur, Kerala for providing facilities and support.

\section{References}

[1] H. Magen. Fertigation: An overview of some practical aspects. Fert. News, 40 (12), 1995, 97-100.

[2] J. Hagin and A. Lowengart. Fertigation for minimizing environmental pollution by fertilizers. Fertilizer Research, 43(1), 1995, 127130.

[3] R.K Sivanappan. and M.V. Ranghaswami. Technology to take 100 tons per acre in sugarcane. Kissan World, 32(10), 2005, 35-38.

[4] P.S Shirgure, Lallan Ram, R.A. Marathe and R.P. Yadhav. Effect of nitrogen fertigation on vegetative growth and leaf nutrient content of acid lime (Citrus aurantifolia Swingle) in central India. Indian J. Soil Conservation, 27(1), 1999, 45-49.

[5] T.B.S Rajput. and Neelam Patel. Yield response of Okra (Abelmoschus esculentus L.) to different levels of fertigation. Annals of Agricultural Research, 23 (1), 2002, 164-165.

[6] R L Mikkelse. Phosphorous fertilization through drip irrigation. J. Prod.Agric. 2(3), 1989, $279-286$.

[7] Z.H, Zhang, Q.Y. Chen, L.H. Gao, J.J. Wang, J. Shen, Z.M. Li and X.Y. Zhang. Research on the development and countermeasures of facility vegetable industry, China. Vegetables, 5, 2010, 1-3. 